\title{
Peran Kepemimpinan Ketua Kelompok Tani Oel'nasi, di Desa Sallu Kecamatan Miomaffo Barat, Kabupaten Timor Tengah Utara
}

\author{
Marsianus Falo ${ }^{\mathrm{a}}$ \\ ${ }^{a}$ Fakultas Pertanian, Universitas Timor, Kefamenanu, TTU - NTT, Indonesia.
}

\section{Article Info}

\section{Article history:}

Received 18 Mei 2016

Received in revised form 28 Juni 2016

Accepted 15 Juli 2016

\section{Keywords:}

Kepemimpinan

Kelompok Tani

Oel'nasi

Sallu

\section{Abstrak}

Penelitian ini dilakukan di Kelompok tani Oel'nasi Desa Sallu Kecamatan Miomaffo Barat, dengan tujuan 1) mengetahui gambaran kegiatan kelompok tani Oel'nasi di Desa Sallu, 2) mengetahui persepsi anggota kelompok terhadap peran kepemimpinan ketua kelompok tani Oel'nasi di Desa Sallu. Metode yang digunakan dalam penelitian ini adalah metode survei, Untuk menjawab tujuan pertama digunakan metode deskriptif dan untuk tujuan kedua digunakan skala pengukuran Likert. Hasil penelitian menunjukan bahwa 1) persepsi anggota kelompok dalam keaktifan di kelompok tani Oel'nasi yaitu berada pada kategori cukup baik dengan total nilai yaitu sebesar $447,45 \%$, dengan nilai rata-rata $74,58 \%$. Nilai ini menunjukkan bahwa anggota kelompok tani selalu beusaha untuk berpartisipasi dalam setiap aktivitas yang berkaitan dengan kelompok tani Oel'nasi; 2) persepsi anggota kelompok terhadap peran kepemimpinan dalam rencana kerja kegiatan yaitu berada pada kategori kurang baik dengan prosentase $67,5 \%$; 3 ) persepsi anggota kelompok terhadap peran kepemimpinan dalam pengorganisasian yaitu berada pada kategori cukup baik dengan total nilai 307,5\%, dengan nilai rata - rata 76,88\%; 4) persepsi anggota kelompok terhadap peran kepemimpinan dalam aspek pelaksanaan yaitu berada pada kategori cukup baik dengan total nila $213,75 \%$, dan total nilai rata - rata yaitu sebesar $71,25 \%$, setiap perencanaan yang telah ditetapkan belum dilaksanakan secara efektif dan efisien, untuk itu perlu adanya penyuluh yang rutin untuk dapat membina dan melatih agar dapat menambah pengetahuan/ sumberdaya petani dalam melakukan suatu kegiatan usahatani agar tujuan yang diinginkan dapat tercapai; dan 5) persepsi anggota kelompok terhadap peran kepemimpinan dalam manajemen yaitu berada pada kategori cukup baik dengan nilai $73,75 \%$. Peran kepemimpinan dalam manajemen masih rendah atau belum optimal. (2016 dipublikasikan oleh Agrimor.

\section{Pendahuluan}

Kehadiran kelompok-kelompok tani yang ada di masyarakat selalu diarahkan untuk semakin terikat oleh kepentingan dan tujuan bersama dalam meningkatkan produksi dan pendapatan dari usahataninya. Kepemimpinan dibutuhkan dalam proses pemberdayaan kelompok tani karena memiliki pengaruh yang kuat terhadap anggotanya guna mencapai tujuan bersama.

Andrew dan Dubrin (2006) mengungkapkan bahwa kepemimpinan diartikan sebagai kekuatan yang dinamis dalam memotivasi dan mengkoordinasi anggota kelompoknya. Untuk itu, dukungan kepemimpinan berkualitas dalam tercapainya mencapai tujuan sangat dibutuhkan baik oleh kelompok taninya maupun oleh anggota kelompok taninya. Kepemimpinan juga memiliki andi dalam mempengaruhi sukses tidaknya kegiatan pemberdayaan terhadap anggota kelompok tani.

Kepemimpinan kelompok tani yang berkualitas tersebut, menjadi suatu keharusan bahwa kelompok tani yang ada harus memiliki gerak atau kekuatan yang dapat menentukan dan mempengaruhi perilaku anggota-anggotanya dalam mencapai tujuan-tujuan secara efektif. Salah satu faktor penting untuk terwujudnya kelompok tani yang efektif adalah berjalannya kepemimpinan dari ketua kelompok tani tersebut. Ketua kelompok dapat dipandang sebagai agen primer untuk efektifnya kelompok, karena peran strategisnya dalam mempengaruhi atau menggerakkan anggota-anggota di kelompoknya untuk mencapai tujuan-tujuan kelompok maupun dari anggota-anggotanya. Ada empa indikator penting dalam melihat berjalannya kepemimpinan dari ketua kelompok, yaitu dilihat dari segi: (1) kekuatan keahlian, (2) kekuatan rujukan, (3) pembawa aspirasi, dan (4) menjadi patner yang memperbaharui.

Dengan berjalannya kepemimpinan di kelompok tani, maka di mungkinkan kelompok tani tersebut mencapai efektivitasnya. Efektivitas kelompok adalah tingkat keberhasilan kelompok untuk mencapai tujuannya. Indikator efektivitas ini mencakup tingkat keberhasilan dalam segi: (1) produktivitas kelompok, (2) moral kelompok, dan (3) tingkat kepuasan dari para anggota. Pengkajian terhadap kepemimpinan ketua kelompok dalam kaitannya dengan pencapaian efektivitas kelompok tani dipandang cukup penting, karena sejauh ini kelompokkelompok tani yang ada belum menunjukkan efektivitas sebagaimana yang diharapkan.

Desa Sallu Kecamatan Miomaffo Barat Kabupaten Timor Tengah Utara (TTU) merupakan suatu daerah yang sebagian besar penduduknya bermata pencaharian sebagai petani, serta terdapat kelompok-kelompok tani sebaga wadah bekumpulnya para petani yang memiliki tujuan bersama, yaitu mengubah kehidupan sosial menjadi lebih sejahtera dengan bantuan Penyuluh Pertanian Lapangan (PPL) yang ditempatkan di daerah tersebut. Setiana, (2005) menyatakan bahwa penyuluhan merupakan suatu sistem pendidikan di luar sekolah untuk petani di pedesaan agar dapat meningkatkan pengetahuan, keterampilan dan sikap mentalnya menjadi lebih produktif sehingga mampu meningkatkan penghasilan keluarga. Penyuluh dibagi ke dalam tiga golongan, yaitu penyuluh pegawai negeri sipil, penyuluh swasta, dan penyuluh swadaya Penyuluh pegawai negeri sipil disebut sebagai penyuluh PNS, diberi tugas, wewenang, tanggung jawab, dan hak secara penuh untuk melakukan kegiatan penyuluhan oleh pejabat yang berwenang pada satuan organisasi lingkup pertanian. Penyuluh swasta merupakan penyuluh yang berasal dari dunia usaha yang mempunyai kompetensi dalam bidang penyuluhan. Sedangkan penyuluhan swadaya merupakan pelaku utama yang berhasil dalam usahanya dan masyarakat lainnya yang mempunyai kesadaran untuk menjadi penyuluh.

Berdasarkan survei awal, petani kelompok tani Oel,nasi di Desa Sallu dikatakan bahwa, petani masih kurang peka dalam mengikuti kegiatan-kegiatan penyuluh dalam berkelompok tani. Dari tujuh kelompok tani yang ada di Desa Sallu, peneliti mengambil salah satu kelompok tani yaitu kelompok tani Oel'nasi.
Kelompok Tani ini telah terbentuk sejak sepuluh tahun yang lalu dan telah memiliki keanggotaan sebanyak 20 orang. Namun sejauh ini kelompok tani Oel'nasi di Desa Sallu masih sangat minim dalam peningkatan kemampuan kelompok tani terhadap aspek-aspek dan fungsi-fungsi kelompok tani masih terdapat beberapa kendala dan salah satunya menjalankan tugas pokok dan fungsi dari kepemimpinan yang ada di kelompok tani Oel'nasi.

Berdasarkan gambaran di atas, maka dikaji tentang peran kepemimpinan ketua kelompok tani Oel'nasi, di desa Sallu kecamatan Miomaffo Barat kabupaten TTU.

\section{Metode}

Penelitian ini dilaksanakan pada bulan Juni-Agustus 2015 di Kelompok Tani Oel'nasi, Desa Sallu, Kecamatan Miomaffo Barat, Kabupaten TTU. Metode yang digunakan dalam penelitian ini yaitu metode survei. Jenis data yang digunakan adalah Data Primer dan Sekunder, Data primer diperoleh melalui wawancara secara langsung dengan petani responden yang berpedoman pada daftar pertanyaan atau kuesioner yang telah di persiapkan, serta pengamatan langsung di lapangan. Sedangkan Data Sekunder dikumpulkan dari literatur literatur yang relevan seperti buku, internet, Dinas Pertanian, serta instans lainnya yang dapat mendukung dan membantu untuk ketersediaan data. Teknik pengambilan sampel yang digunakan adalah metode sensus, sehingga dalam penelitian ini sampel yang diambil adalah semua anggota kelompok tani Oel'nasi yang berjumlah 20 orang.

Analisis data untuk mengetahui tingkat persepsi petani terhadap peran kepemimpinan dilakukan dengan menggunakan alat ukur skala Likert, yaitu skala yang digunakan untuk mengukur sikap, pendapat, dan persepsi seseorang atau sekelompok orang tentang fenomena sosial (Sugiyono, 2011). Dengan Skala Likert, variabel yang akan diukur dijabarkan menjadi indikator variabel, kemudian indikator tersebut dijadikan sebagai titik tolak untuk menyusun itemitem instrument yang dapat berupa pernyataan atau pertanyaan.

Daftar pertanyaan (kuisioner) yang akan digunakan dalam penelitian terlebih dahulu diuji kelayakannya dengan cara menguji validitas dan reliabilitasnya untuk mengetahui sejauh mana tingkat kehandalan dari instrumen yang digunakan. Sugiyono (2009), menyatakan bahwa suatu instrumen dinyatakan valid, apabila instrumen tersebut mampu mengukur apa yang hendak diukur. Reliabilitas adalah kemampuan, keajegan atau stabilitas hasil pengamatan dengan instrumen. Instrumen yang reliabel berarti instrumen apabila digunakan beberapa kali untuk mengukur obyek yang sama akan menghasilkan data yang sama

Validasi dan reliabilitas kuesioner dilakukan sesuai petunjuk Sugiyono (2009). Untuk mengetahui tingkat persepsi anggota kelompok terhadap peran kepemimpinan kelompok tani Oel'nasi dilakukan dengan menggunakan alat ukur skala likert sesuai petunjuk Sugiyono, (2011).

\section{Hasil dan Pembahasan}

\subsection{Gambaran Kelompok Tani Oel'nasi}

Kelompok tani Oel'nasi sudah berdiri sejak tahun 2005 yang bertempat di Desa Sallu Kecamatan Miomaffo Barat Kabupaten TTU. Kemudian pada tanggal 25 Februari 2007, membentuk kepengurusan baru dengan ketua kelompok tani yang baru. Latar belakang terbentuknya kelompok tani Oel'nasi adalah disebabkan oleh keinginan petani untuk dapat berdiskusi dan bertukar pengalaman di bidang pertanian. Oleh karena itu, timbulah inisiatif untuk dapa membentuk kelompok tani yang diberi nama kelompok tani Oel'nasi. Melalui kelompok tani ini, para petani dapat menyalurkan aspirasinya dan menjadi wadah belajar bagi para anggota kelompok. Kelompok tani Oel'nasi memiliki visi dan misi dalam menjalankan kegiatan kelompok taninya, yakni, visi: "Menjadi 
Kelompok yang handal dan kuat dalam usaha pertanian demi terwujudnya kesejahteraan anggota dan keluarganya". Misi: 1) Meningkatkan kerja sama yang baik antara sesama anggota dalam kegiatan-kegiatan kelompok; 2) Meningkatkan produksi pertanian dari 2-3 ton/ha menjadi 3,5 ton/ha; 3) Membuka jejaringan dengan pihak atau instansi lain; dan 4) Meningkatkan pemupukan modal dengan mencari dana melalui kerja kelompok.

Struktur kelompok adalah hal-hal yang dibutuhkan untuk menunjang bejalannya kegiatan kelompok dalam mencapai tujuan. Struktur organisasi kelompok tani Oel'nasi mempunyai pengurus kelompok yaitu orang-orang yang diberi mandat oleh anggota untuk menjalankan kegiatan-kegiatan kelompok yang terdiri dari: Ketua, Sekretaris, Bendahara,dan Seksi-seksi.

Gambaran kegiatan kelompok tani Oel'nasi di Desa Sallu Kecamatan Miomaffo Barat Kabupaten TTU sesuai hasil penelitian dalam peningkatan kelompok tani terhadap kegiatan-kegiatan yang dilaksanakan yaitu keaktifan anggota kelompok tani, tingkat pertemuan dan kerjasama dalam kelompok, serta pendapatan kelompok.

Keaktifan anggota dalam kelompok tani Oel'nasi di Desa Sallu dapat dilihat dari tingkat kehadiran anggota dalam mengikuti pertemuan, pelaksanaan program kerja, penyelesaian permasalahan, kemampuan kelembagaan, serta partisipassi dalam mencari dan menyebarkan informasi/inovasi dalam kelompok tani. Tingkat pertemuan diukur dengan frekuensi anggota kelompok dalam menghadiri pertemuan dan musyawarah kerja kelompok tani. Pelaksanaan dalam kegiatan dapat diukur dari pelaksanaan kegiatan kelompok dan temu lapang dengan anggota kelompok. Sedangkan program kerja diukur melalui rencana kerja dan pelaksanaan program. Permasalahan dapat diukur dari identifikasi, penyelesaian, dan pengambilan keputusan. Kelembagaan dapat diukur melalui kerjasama annggota kerjasama dengan yang lain, serta keterlibatan dalam kelompok. Sementara untuk program informasi/inovasi dapat diukur melalui menerima, mencari dan menyebarkan informasi dalam hal kelompok tani. Berikut struktur kelompok tani Oel'nasi Desa Sallu, Kec. Miomaffo Barat Kabupaten Timor Tengah Utara.

Tingkat keaktifan anggota kelompok tani Oel'nasi di Desa Sallu Kecamatan Miomaffo Barat Kabupaten Timor Tengah Utara berdasarkan nilai dari masingmasing sub variabel dapat dilihat pada Tabel 1 .

\begin{tabular}{clcr}
\multicolumn{5}{c}{ Tabel 1. Rekapitulasi Kategori Keaktifan Anggota Kelompok Tani. } \\
\hline No & \multicolumn{1}{c}{ Indikator } & Kategori & $\%$ \\
\hline 1 & Keaktifan Anggota dalam Kelompok Tani & Baik & 80,50 \\
2 & Pertemuan dan Musyawarah Kelompok & Cukup Baik & 75,00 \\
3 & Pelaksanaan Kegiatan dan Temu Lapang & Cukup Baik & 75,25 \\
4 & Rencana Kerja dan Program Kerja & Cukup Baik & 70,20 \\
5 & Identifikasi dan Rumusan Masalah & Cukup Baik & 70,00 \\
6 & Kelembagaan Kelompok Tani & Cukup Baik & 77,75 \\
7 & Informasi dan inovasi & Cukup Baik & 75,25 \\
\hline \multicolumn{2}{l}{ Total } & & 523,95 \\
\hline & Rata-rata & 74,85 \\
\hline
\end{tabular}

Sumber: data primer (diolah), 2015

Dari data tersebut, tertuang Rekapitulasi kategori keaktifan Anggota Kelompok Tani menunjukan, tingkat keaktifan kelompok tani Oel'nasi berada pada kategori cukup baik, total nilai dalam semua indikator yaitu $529,95 \%$ dengan nilai rata - rata $75,71 \%$. Nilai ini menunjukkan bahwa partisipasi anggota kelompok tani termasuk dalam kategori cukup baik. Hal ini berarti bahwa anggota kelompok tani selalu berusaha untuk berpartisipasi dalam setiap aktivitas yang berkaitan dengan kelompok tani Oel'nasi.

\subsection{Persepsi Anggota kelompok Terhadap Peran Kepemimpinan Ketua} Kelompok Tani Oel'nasi

Pemimpin ketua kelompok memiliki peranan yang sangat penting dalam mengelola kelompok taninya. Sesuai dengan hasil penelitian di lokasi peran kepemimpinan ketua kelompok tani Oel'nasi meliputi : Rencana Kerja Kegiatan Pengorganisasian, Aspek pelaksanaan, dan Manajemen.

\section{a. Rencana Kerja Kegiatan}

Rencana Definitif Kelompok (RDK) menurut Permentan No. 82 Tahun 2013 adalah rencana kerja usahatani dari kelompoktani untuk satu tahun, yang disusun melalui musyawarah dan berisi rincian tentang sumber daya dan potensi wilayah, sasaran produktivitas, pengorganisasian dan pembagian kerja, serta kesepakatan bersama dalam pengelolaan usahatani. Sesuai dengan hasil penelitian di lokasi, kemampuan untuk merencanakan merupakan hal yang sangat penting dalam melakukuan suatu kegiatan. Perencanaan kegiatan yang biasanya dilakukan kelompok tani Oel'nasi yaitu adalah hasil perencanaan secara bersama antara pengurus dan anggota kelompok tani dengan bimbingan penyuluh pertanian.

Sesuai dengan Tabel 2. perencanaan Kerja Kegiatan kepemimpinan pada kelompok tani Oel'nasi jumlah penilaian responden yang terbanyak dalam kategori cukup Baik. Rencana kerja kegiatan Kepemimpinan ketua kelompok tani Oel'nasi kemampuan dalam menyusun perencanaan belum mencapai kategori baik, maka penyuluh pertanian perlu mendampingi dan membimbing petani atau kelompok dalam menyusunya, sehingga rencana yang disusun sesuai dengan kebutuhan dan kemampuan petani dalam menjalankan kegiatan usahataninya.
Tabel 2. Kategori Rencana Kerja Kegiatan Peran Kepemimpinan Kelompok Tani Oel'nasi

\begin{tabular}{cccccc}
\hline \multirow{2}{*}{ No } & Kategori Rencana & \multicolumn{4}{c}{ Jumlah } \\
\cline { 3 - 6 } & Kerja Kegiatan & Nilai & Skor & ns & $\%$ \\
\hline 1 & Baik & 4 & 4 & 16 & 20 \\
2 & Cukup Baik & 8 & 3 & 24 & 40 \\
3 & Kurang Baik & 6 & 2 & 12 & 30 \\
4 & Tidak Baik & 2 & 1 & 2 & 10 \\
\hline & Jumlah & 20 & & 54 & 100 \\
\hline Skor maksimum (4 x 20) & \multicolumn{5}{c}{80}
\end{tabular}

$\%$ Rencana kerja kegiatan $\quad(54 / 80) \times 100 \%=67,5 \%$

Sumber: data primer (diolah), 2015

Keterangan : rentangan kategori $<50 \%=$ tidak baik; $\geq 50=$ kurang baik; $\geq 75=$ cukup baik; $\geq 80=$ baik.

\section{b. Pengorganisasian}

Organisasi merupakan kelompok orang yang mempunyai kegiatan dan bekerja bersama-sama untuk mencapai suatu tujuan tertentu. Pengorganisasian kelompok tani berfungsi supaya kelompok tani dapat melaksanakan fungsi secara optimal, harus ada dorongan dari pengurus kelompok dan anggotanya. Pentingnya peran aktif anggota kelompok dalam menghidupkan kelompoknya perlu didukung oleh kepemimpinan kelompok yang baik yakni dicirikan agar memadainya pelayanan pengurus terhadap kepentingan anggota, sehingga dinamika kelompok akan terus berkembang. Pengukuran peran kepemimpin kelompok tani dapat dilihat berdasarkan kemampuannya untuk menjalankan roda organisasi dan memantau perkembangan organisasi. Selain itu dapat pula dilihat dari kemampuan dalam memecahkan masalah, hasil rapat dalam bentuk notulen, dan pembagian tugas.

\section{- Kemampuan Organisasi}

Faktor kepemimpinan sering kali menentukan kualitas kerja para anggota karena anggota berpendapat bahwa pimpinan adalah seseorang yang dapat mengatur dan menjalankan suatu pekerjaan dengan setuju. Pengaturan dan pemantauan terhadap tugas juga menentukan keberhasilan tugas tersebut. Jika pimpinan ikut terlibat dalam pengaturan dan pemantauan penyelesaian tugas, maka hasil kerja yang didapat akan lebih efektif dan efisien. Seorang pimpinan memiliki sikap yang terbuka terhadap pendapat, saran, maupun ide yang dikemukakan anggotanya untuk menyelesaikan suatu tugas.

Tabel 3. Kategori Peran Kepemimpinan Kelompok Tani Oel'nasi dalam Kemampuan Organisasi.

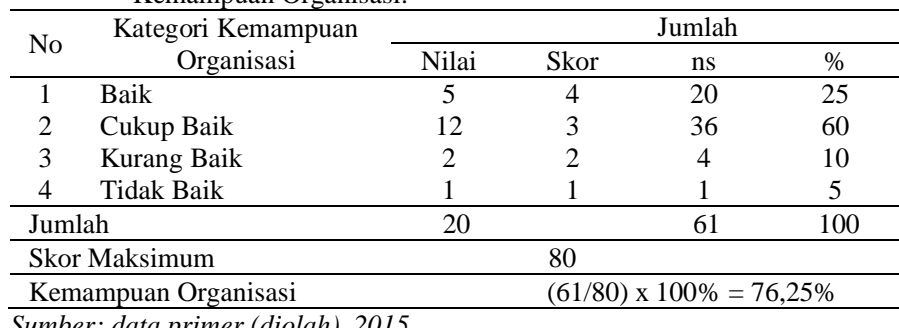

Sumber: data primer (diolah), 2015

Sesuai dengan Tabel 3. penilaian responden terhadap peran kepemimpinan dalam kemampuan organisasi responden yang paling banyak memilih kategori cukup baik, data ini diolah dan hasil yang diperoleh dari penilaian responden yaitu $76,25 \%$. Untuk itu Peran Kepemimpinan Kelompok Tani Oel'nasi Dalam Kemampuan Organisasi berada dalam kategori cukup baik oleh karena itu dalam pelanksanaan tugas yang berkaitaan dengan organisasi dalam kelompok tani perlu ada pendapingan dalam rangka pencerahan terkait menajemen berorganisasi dari penyuluh pertanian.

\section{- Kemampuan Dalam Memecahkan Masalah}

Adanya perhatian terhadap permasalahan yang terjadi juga akan semakin meningkatkan kedekatan pimpinan dan anggota, bentuk perhatian yang diberikan sesetujunya hanya bersifat memantau permasalahan saja dan jika anggota belum bisa menemukan jalan keluar yang tersetuju, pimpinan sesetujunya memberikan saran dan pendapatnya untuk mengatasi masalah yang timbul. Sesetujunya dalam menyelesaikan masalah yang ada para anggota juga ikut dilibatkan, sehingga pimpinan tidak berkesan otoriter.

Tabel 4. Kategori Peran Kepemimpinan Kelompok Tani Oel'nasi Kemampuan dalam Memecahkan

\begin{tabular}{cccccc}
\hline \multirow{2}{*}{ No } & Kategori Kemampuan & \multicolumn{4}{c}{ Jumlah } \\
\cline { 3 - 6 } & Memecahkan Masalah & Nilai & Skor & Ns & $\%$ \\
\hline 1 & Baik & 6 & 4 & 24 & 30 \\
2 & Cukup Baik & 10 & 3 & 30 & 50 \\
3 & Kurang Baik & 3 & 2 & 6 & 15 \\
4 & Tidak Baik & 1 & 1 & 1 & 5 \\
\hline Jumlah & 20 & \multicolumn{3}{c}{80} \\
\hline \multicolumn{2}{l}{ Skor Maksimum } & \multicolumn{3}{l}{ Kemampuan dalam Memecahkan Masalah } & $(64 / 80) \times 100 \%=76,25 \%$ \\
\hline
\end{tabular}

Sumber: data primer (diolah), 2015 
Sesuai dengan Tabel 4. penilaian responden pada kategori cukup setuju, dalam kategori baik, data diolah dan hasil yang dicapai yaitu 76,25\%. Pada item ini peran pemimpin dalam memecahkan masalah masih dalam kategori cukup baik. Dalam item ini perlu ada pendapingan lagi sehingga dalam pelaksanaannya semakin hari semin berkembang sampai pada taraf baik dan bahkan sangat baik.

\section{- Hasil Rapat Dalam Bentuk Notulen}

Sesuai dengan hasil penelitian dilokasi, hasil rapat dalam bentuk notulen Anggota kelompok tani masih rendah tingkat kesadarannya dalam melaksanakan kesepakatan dan keputusan kelompok, tingkat kehadiran anggota kelompok tani dalam pertemuan rapat hasil dalam bentuk notulen belum optimal dan tidak rutin.

Tabel 5. Kategori Peran Kepemimpinan Kelompok Tani Oel'nasi Hasil Rapat dalam Bentuk Notulen

\begin{tabular}{llcccc}
\hline \multirow{2}{*}{ No } & Kategori Hasil Rapat & \multicolumn{3}{c}{ Jumlah } \\
\cline { 3 - 6 } & Dalam Bentuk Notulen & Nilai & Skor & Ns & $\%$ \\
\hline 1 & Baik & 7 & 4 & 28 & 35 \\
2 & Cukup Baik & 10 & 3 & 30 & 50 \\
3 & Kurang Baik & 2 & 2 & 4 & 10 \\
4 & Tidak Baik & 1 & 1 & 1 & 5 \\
\hline Jumlah & 20 & & 63 & 100 \\
\hline Skor Maksimum & \multicolumn{5}{l}{80} \\
\hline Hasil Rapat dalam bentuk Notulen & &
\end{tabular}

Tabel 5. menunjukkan penilaian terbanyak dalam kategori cukup baik, penilaian responden dalam kategori cukup baik yang diperoleh adalah 78,75\% Predikat ini menunjukan masih ada hal-hal yang perlu diditingkatkan dalam pelaksanaan tugas oleh karena itu perlu adanya pendampingan atau bimbingan sehingga hal-hal yang belum maksimal dalam pelaksanaan dapat dimaksimalkan.

\section{- Pembagian Tugas kelompok Tani Oel’nasi}

Pembagian tugas pengurus dalam kelompok tani Oel'nasi merata, tetapi. Tugas yang dipercayakan kepada pengurus kelompok belum terlaksana dengan baik. Disebabkan karena tingkat pengetahuan sumber daya manusia dan keterampilan yang sangat terbatas. Kerjasama antara kelompok tani untuk melakukan usaha bersama dalam rangkah mendukung usahatani masih lemah.

Tabel 6. Kategori pengorganisasian Peran Kepemimpinan Kelompok dalam Pembagian Tugas Kelompok Tani Oel'nasi

\begin{tabular}{clcccc}
\hline \multirow{2}{*}{ No } & Kategori Pembagian & \multicolumn{3}{c}{ Jumlah } \\
\cline { 3 - 6 } & \multicolumn{1}{c}{ Tugas Kelompok } & Nilai & Skor & Ns & $\%$ \\
\hline 1 & Baik & 5 & 4 & 20 & 25 \\
2 & Cukup Baik & 12 & 3 & 36 & 60 \\
3 & Kurang Baik & 2 & 2 & 4 & 10 \\
4 & Tidak Baik & 1 & 1 & 1 & 5 \\
\hline Jumlah & 20 & \multicolumn{5}{l}{} \\
\hline Skor Maksimum & \multicolumn{5}{c}{$(61 / 80) \times 100 \%=76,25 \%$} \\
\hline Pembagian Tugas Kelompok &
\end{tabular}

Sumber: data primer (diolah), 2015

Berdasarkan Tabel 6. menunjukkan bahwa, dalam kategori pembagian tugas kelompok tani cukup baik. Penilaian responden dalam kategori cukup baik data diolah yaitu sebanyak $76,25 \%$. Hal ini menunjukan belum maksimal dalam pembagian tugas. Dalam kategori ini juga perlu adanya pendampingan untuk mencapai kategori yang baik dalam hal pembagian tugas.

Tabel 7. Penilaian Setiap Sub Variabel Peran Kepemimpinan Kelompok Tani Oel'nasi

\begin{tabular}{clcc}
\hline No & \multicolumn{1}{c}{ Kategori } & Prosentase (\%) & Ket \\
\hline 1 & Kemampuan Organisasi & 76,25 & Cukup baik \\
2 & Kemampuan Memecahkan masalah & 76,25 & Cukup baik \\
3 & Hasil Rapat dalam Bentuk Notulen & 78,75 & Cukup baik \\
4 & Pembagian Tugas & 76,25 & Cukup baik \\
\hline & Rata-rata & 76,88 & Cukup baik \\
\hline
\end{tabular}

Sumber: data primer (diolah), 2015

Tabel 7. menjelaskan bahwa penilaian peran kepemimpinan dalam Kemampuan organisasi adalah $76,25 \%$ sehingga termasuk dalam kategori cukup baik, nilai kemampuan dalam memecahkan masalah 76,25 (cukup baik), nilai hasil rapat dalam bentuk notulen 78,75 (cukup baik), dan nilai Pembagian tugas 76,25 (cukup baik). Sehingga penilaian rata - rata dari anggota kelompok tani Oel'nasi terhadap peran kepemimpinan dalam organisasi adalah 76,88\% yang menunjukkan kategori cukup baik. semuanya masih berada dalam kategori cukup baik oleh karena itu semua aspek yang termuat dalam peran kepemimpinan ini perlu ada pendapingan secara kontinu sehingga menjadi bagian dari proses belajar menuju kesempurnaan.

\section{c. Aspek Pelaksanaan}

Secara konseptual peran kepemimpinan kelompok tani merupakan suatu gambaran tentang kegiatan-kegiatan kelompok tani yang dikelola berdasarkan kesepakatan anggotanya. Peranan kepemimpinan kelompok tani akan semakin meningkat apabila dapat menumbuhkan kekuatan-kekuatan yang dimiliki dalam kelompok itu sendiri untuk dapat menggerakkan dan mendorong perilaku anggotanya kearah pencapaian tujuan kelompok sehingga kelompok tani tersebut akan berkembang menjadi lebih dinamis. Kelompok tani dapat berkembang secara dinamis jika di dukung oleh seluruh kegiatan yang inisiatif, memiliki daya kreatif, dan tindakan tindakan nyata yang dilakukan oleh seluruh anggota kelompok tani dalam melaksanakan kegiatan-kegiatan yang telah disepakati bersama.

\section{- Kerja Lahan Bersama}

Dalam kegiatan kerja lahan bersama anggota kelompok dapat saling berinteraksi untuk meningkatkan pengetahuan, keterampilan dan sikap serta tumbuh dan berkembangnya kemandirian dalam berusaha tani. Kelompok tani sebagai sarana kerjasama antar anggota kelompok tani dengan harapan agar usaha tani akan lebih efisien, serta lebih mampu menghadapi ancaman, tantangan, hambatan, dan gangguan yang dihadapi. Kelompok tani sebagai satu kesatuan usaha yang dapat dikembangkan untuk mencapai skala ekonomi, dipandang dari segi kualitas, kuantitas dan kontinuitas.

Tabel 8. Kategori Peran Kepemimpinan Kelompok Tani Oel'nasi dalam Kerja Lahan Bersama

\begin{tabular}{llcccc}
\hline \multirow{2}{*}{ No } & \multicolumn{1}{c}{$\begin{array}{c}\text { Kategori Kerja Lahan } \\
\text { Bersama }\end{array}$} & Nilai & Skor & Ns & $\%$ \\
\cline { 3 - 6 } & & 8 & 4 & 32 & 40 \\
2 & Baik & 10 & 3 & 30 & 50 \\
2 & Cukup Baik & 1 & 2 & 2 & 5 \\
3 & Kurang Baik & 1 & 1 & 1 & 5 \\
4 & Tidak Baik & 20 & 65 & 100 \\
\hline Jumlah & \multicolumn{3}{c}{80} \\
\hline \multicolumn{2}{l}{ Skor Maksimum }
\end{tabular}

Kerja Lahan Bersama $\quad(65 / 80) \times 100 \%=81,25 \%$

Sumber: data primer (diolah), 2015

Sesuai dengan Tabel 8. peran kepemimpinan kelompok tani Oel'nasi dalam kerja lahan bersama penilaian dari responden yaitu dalam kategori baik, dalam kategori baik data diolah dan hasil yang diperoleh adalah $81,25 \%$.

\section{- Controuling atau Pengawasan}

Dalam pengawasan kegiatan kelompok tani yaitu dengan mengadakan pertemuan kelompok secara rutin, menetapkan agenda pertemuan secara jelas, dalam setiap pertemuan diawali dengan laporan perkembangan keuangan kelompok dan laporan perkembangan kegiatan, memberi kesempatan kepada semua anggota yang hadir untuk memberikan tanggapan dan pertanyaanpertanyaan sehubungan dengan laporan perkembangan yang disampaikan, memberi tanggapan positif atas usul dan saran dari setiap anggota kelompok yang hadir, mendiskusikan setiap kegiatan yang akan dilaksanakan dengan cara musyawarah dengan anggota kelompok dan selalu berupaya untuk memperbaiki manajemen kelompok.

Tabel 9. Kategori Aspek Pelaksanaan Kegiatan Peran Kepemimpinan Kelompok Tani Oel'nasi dalam Controling atau Pengawasan

\begin{tabular}{|c|c|c|c|c|c|}
\hline \multirow{2}{*}{ No } & \multirow{2}{*}{$\begin{array}{c}\text { Kategori Controuling atau } \\
\text { Pengawasan }\end{array}$} & \multicolumn{4}{|c|}{ Jumlah } \\
\hline & & Nilai & Skor & Ns & $\%$ \\
\hline 1 & Baik & 4 & 4 & 16 & 20 \\
\hline 2 & Cukup Baik & 8 & 3 & 24 & 40 \\
\hline 3 & Kurang Baik & 5 & 2 & 10 & 25 \\
\hline 4 & Tidak Baik & 3 & 1 & 3 & 15 \\
\hline \multicolumn{2}{|c|}{ Jumlah } & 20 & & 53 & 100 \\
\hline \multicolumn{2}{|c|}{ Skor Maksimum } & \multicolumn{2}{|c|}{80} & & \\
\hline \multicolumn{2}{|c|}{ Controling atau Pengawasan } & \multicolumn{4}{|c|}{$(53 / 80) \times 100 \%=66,25 \%$} \\
\hline
\end{tabular}

\section{Sumber: data primer (diolah), 2015}

Sesuai dengan Tabel 9. penilaian responden terhadap peran kepemimpinan dalam kategori controlling atau pengawasan adalah kategori cukup baik, dalam kategori cukup baik data diolah dan hasil yang diperoleh yaitu 66,25.

\section{- Rapat Evaluasi Kegiatan Kelompok Tani}

Rapat Evaluasi kegiatan kelompok tani yaitu menilai dan mengukur hasil dari berbagai kegiatan usaha tani yang telah dilakukan seperti bermusyawarah mengenai berbagai kekurangan yang dihadapi dalam usaha tani, baik kekurangan sarana, prasarana maupun modal. Selain itu kelompok tani juga berusaha meningkatkan kualitas dan kuantitas dalam usaha tani yang dilaksanakan.

Sesuai dengan hasil penelitian di lokasi penilaian anggota kelompok terhadap peran kepemimpinan dalam rapat evaluasi kegiatan kelompok tani yaitu kategori cukup setuju, dalam kategori cukup setuju data diolah dan hasil yang diperoleh adalah 66,25 . 
Tabel 10. Kategori Aspek Pelaksanaan Kegiatan Peran Kepemimpinan Kelompok Tani Oel'nasi dalam Rapat Evaluasi Kegiatan

\begin{tabular}{llcccc}
\hline \multirow{2}{*}{ No } & Kategori Rapat Evaluasi & \multicolumn{5}{c}{ Jumlah } \\
\cline { 3 - 6 } & Kegiatan Kelompok & Nilai & Skor & Ns & $\%$ \\
\hline 1 & Baik & 5 & 4 & 20 & 25 \\
2 & Cukup Baik & 7 & 3 & 21 & 35 \\
3 & Kurang Baik & 4 & 2 & 8 & 20 \\
4 & Tidak Baik & 4 & 1 & 4 & 20 \\
\hline Jumlah & 20 & 53 & 100 \\
\hline Skor Maksimum & \multicolumn{5}{c}{$(53 / 80) \times 100 \%=66,25 \%$} \\
\hline Rapat Evaluasi Kegiatan Kelompok & \multicolumn{5}{l}{}
\end{tabular}

Sumber: data primer (diolah), 2015

Tabel 11. Penilaian Setiap Sub Variabel Peran Kepemimpinan Kelompok Tani Oel'nasi dalam Aspek Pelaksanaan

\begin{tabular}{llcc}
\hline No & \multicolumn{1}{c}{ Kategori } & Prosentase $(\%)$ & Keterangan \\
\hline 1 & Kerja lahan bersama & 81,25 & Baik \\
2 & Controuling atau Pengawasan & 66,25 & Kurang baik \\
3 & Rapat evaluasi kegiatan & 66,25 & Kurang baik \\
\hline & Rata-rata & 71,25 & Cukup baik \\
\hline
\end{tabular}

Sumber: data primer (diolah), 2015

\section{d. Manajemen}

Dari hasil penelitian menunjukkan bahwa Sebagian besar petani / kelompok tani masih bersifat tradisional dengan modal keterampilan dan pengetahuan serta teknologi terbatas/rendah. Kelompok tani belum menjadi kelompok solusi sebagian besar dibentuk hanya untuk mengakses bantuan, sehingga tingkat kreativitas bertani belum terlihat, kemampuan pengurus kelompok tani dalam usaha agribisnis belum memadai dalam mengembangkan uasaha tani merupakan kendala yang sudah sering terjadi pada kelompok umumnya.

Pengertian manajemen dapat berkaitan dengan sistem yang diterapkan oleh pimpinan serta mengandalkan anggota. Manajemen kinerja adalah keseluruhan kegiatan yang dilakukan untuk meningkatkan kinerja organisasi, termasuk kinerja setiap individu dan kelompok kerja untuk menciptakan hubungan dan memastikan komunikasi yang efektif secara terus-menerus dalam kemitraan antara anggota dengan pemimpin kelompok.

Tabel 12. Kategori Manajemen Kepemimpinan Kelompok Tani Oel'nasi

\begin{tabular}{clcccc}
\hline \multirow{2}{*}{ No } & \multirow{2}{*}{ Kategori Manajemen } & \multicolumn{4}{c}{ Jumlah } \\
\cline { 3 - 6 } & Baik & Nilai & Skor & Ns & $\%$ \\
\hline 1 & 3 & 4 & 12 & 15 \\
2 & Cukup Baik & 14 & 3 & 42 & 70 \\
3 & Kurang Baik & 2 & 2 & 4 & 10 \\
4 & Tidak Baik & 1 & 1 & 1 & 5 \\
\hline Jumlah & 20 & 59 & 100 \\
\hline Skor Maksimum & \multicolumn{5}{c}{$(50 / 80) \times 100 \%=73,75 \%$} \\
\hline Manajemen & \multicolumn{5}{c}{}
\end{tabular}

Sumber: data primer (diolah), 2015

Berdasarkan Tabel 12. menunjukkan bahwa penilaian dari responden yang paling banyak yaitu kategori cukup baik. Dari Tabel di atas data diolah dan hasil yang diperoleh adalah 73,25 .

\section{Simpulan}

Persepsi anggota kelompok dalam keaktifan di kelompok tani Oel'nasi yaitu berada pada kategori cukup baik dengan total nilai yaitu sebesar $447,45 \%$, dengan nilai rata-rata $74,58 \%$. Nilai ini menunjukkan bahwa anggota kelompok tani selalu beusaha untuk berpartisipasi dalam setiap aktivitas yang berkaitan dengan kelompok tani Oel'nasi. Persepsi anggota kelompok terhadap peran kepemimpinan dalam rencana kerja kegiatan yaitu berada pada kategori kurang baik dengan prosentase $67,5 \%$. Persepsi anggota kelompok terhadap peran kepemimpinan dalam pengorganisasian yaitu berada pada kategori cukup baik dengan total nilai $307,5 \%$, dengan nilai rata - rata $76,88 \%$. Persepsi anggota kelompok terhadap peran kepemimpinan dalam aspek pelaksanaan yaitu berada pada kategori cukup baik dengan total nilai $213,75 \%$, dan total nilai rata - rata yaitu sebesar $71,25 \%$, setiap perencanaan yang telah ditetapkan belum dilaksanakan secara efektif dan efisien, untuk itu perlu adanya penyuluh yang rutin untuk dapat membina dan melatih agar dapat menambah pengetahuan/ sumberdaya petani dalam melakukan suatu kegiatan usahatani agar tujuan yang diinginkan dapat tercapai. Persepsi anggota kelompok terhadap peran kepemimpinan dalam manajemen yaitu berada pada kategori cukup baik dengan nilai $73,75 \%$. Peran kepemimpinan dalam manajemen masih rendah atau belum optimal.

\section{Pustaka}

Andrew J, Dubrin. 2006. The Complete Idiot's Guides to Leadership 2nd Edition. Jakarta(ID): Prenanda.

Departemen Pertanian. 2007. Peraturan Menteri Pertanian. Nomor 273/Kpts/Ot.160/4/2007 Tanggal 13 April 2007 Tentang Pedoman Pembinaan Kelembagaan Petani.

Setiana L. 2005. Teknik Penyuluhan dan Pemberdayaan. Bogor(ID): Ghalia Indonesia.
Sugiyono. 2011. Statistika untuk Penelitian. Bandung: CV Alfabeta. Sugiyono, 2009. Metode Penelitian Kuantitatif, Kualitatif dan R\&D. Bandung: Alfabeta. 